JISIP: Jurnal Ilmu Sosial dan Ilmu Politik

ISSN. 2442-6962

Vol. 9 No. 2 (2020)

\title{
STRATEGI PENGEMBANGAN BADAN USAHA MILIK DESA (BUMDES) ATAS KERJASAMA BADAN USAHA MILIK SWASTA
}

\author{
Nanang Bagus \\ Program Studi Ilmu Administrasi Negara, Universitas Tribhuwana Tunggadewi \\ Email: nanangbagus1997@gmail.com
}

\begin{abstract}
Village- owned enterprises emerged as a new economic force in rural areas. The role of the village government and local communities in maximized to mobilize local economic potential for improving social welfare and villagers. This study aims to determine the strategy of the village government in managing villageowned enterprises and the cooperation between the village government and the private sector in managing village- owned enterprises. This type of research is literacy research and the data used in this study are secondary data collected through library data (newspapers, magazines, and documents), reading and processing previous research materials. The results of this study indicate that village- owned enterprises are a manifestation of the participation of the village community as a whole, so that they do not create business models that are influenced by leadership by certain group at the village level, as well as implementation which is a series of concepts that guide the implementation of a job, leadership and way of acting. And the existence of collaborative governance which a concept in government management as a facilitation process by various is intitutions both governmen, community and private parties that aim to solve common problems that cannot be resolved by one agency.
\end{abstract}

Keywords: village-owned enterprises, governance of village-owned enterprises, collaborative governance

\begin{abstract}
Abstrak. Badan usaha milik desa muncul sebagai kekuatan ekonomi baru di wilayah perdesaan. Peran pemerintah desa dan masyarakat lokal dimaksimalkan untuk menggerakkan potensi ekonomi lokal bagi peningkatan kesejahteraan sosial dan wargadesa. Penelitian ini bertujuan untuk mengetahui strategi pemerintah desa dalam mengelolah badan usaha milik desa dan kerjasama pemerintah desa dan Pihak swasta dalam mengelola badan usaha milik desa. Jenis penelitian ini adalah penelitan literasi dan data yang digunakan dalam penelitian ini adalah jenis data sekunder yang dikumpulkan melalui data pustaka (koran, majalah, dan dokumen), membaca serta mengolah bahan penelitian terdahulu. Hasil dari penelitian ini menunjukan bahwa badan usaha milik desa merupakan perwujudan partisipasi masyarakat desa secara keseluruhan, sehingga tidak menciptakan model usaha yang di pengaruhi kepimpinan oleh kelompok tertentu ditingkat desa, juga implementasi yang merupakan suatu rangkaian konsep yang menjadi pedoman dalam pelaksanaan suatu pekerjaan, kepemimpinan dan cara bertindak. Dan adanya Collaborative governance yang merupakan konsep dalam manajemen Pemerintahan sebagai proses fasilitasi oleh berbagai institusi baik Pemerintah, Masyarakat maupun pihak Swasta yang bertujuan untuk menyelesaikan masalah bersama yang tidak bisa di selesaikan oleh satu instansi.
\end{abstract}

Kata Kunci: Badan Usaha Milik Desa, Tata Kelola Badan Usaha Milik Desa, Collaborative Governance

\section{PENDAHULUAN}

Badan Usaha Milik Desa selanjutnya disingkat dengan BUMDes adalah muncul sebagai kekuatan ekonomi baru di wilayah perdesaan. UU No 6 tahun 2014 tentang Desa memberikan paying hukum atas BUMDes sebagai pelaku ekonomi yang mengelola potensi desa secara kolektif untuk meningkatkan kesejahteraan warga desa.Lahirnya peraturan diatas, memberikan inisiatif BUMDes untuk muncul sebagai perubahan pembangunan desa.

BUMDes hadir sebagai wadah dalam menggerakan potensi ekonomi lokal bagi peningkatan kesejahteraan sosial dan ekonomi warga desa. Peran pemerintah desa dan masyarakat lokal 
JISIP: Jurnal Ilmu Sosial dan Ilmu Politik

ISSN. 2442-6962

Vol. 9 No. 2 (2020)

dimaksimalkan untuk menggerakkan potensi ekonomi lokal bagi peningkatan kesejahteraan sosial dan warga desa.

Menurut Yunanto dkk (2014:7) keunikan BUMDes merupakan sebuah usaha desa milik kolektif yang digerakkan oleh aksi kolektif antara pemerintah desa dan masyarakat. BUMDes sebagai salah satu lembaga ekonomi yang beroperasi di pedesaan harus memiliki perbedaan dengan lembaga ekonomi pada umumnya. Hal ini dimaksudkan agar keberadaan dan kinerja BUMDes mampu memberikan kontribusi yang signifikan terhadap peningkatan kesejahteraan warga desa.

Jika kelembagaan ekonomi kuat dan ditopang kebijakan yang memadai, pertumbuhan ekonomi yang disertai pemerataan distribusi asset kepada rakyat secara luas agar mampu menanggulangi berbagai permasalahan ekonomi di pedesaan. Tujuan akhirnya, BUMDes sebagai instrumen modal sosial (social capital) yang diharapkan mampu menjembatani upaya penguatan ekonomi di pedesaan. (sumber: Pusat kajian Dinamika Sistem Pembangunan 2007).

Untuk mencapai langkah tersebut di perlukan kerjasama swasta atau Badan Usaha Milik Swasta (BUMS) yang memiliki definisi. Badan Usaha Milik Swasta (BUMS) dibedahkan dua jenis yaitu badanusaha Milik swasta dalam negeri dan badan usaha swasta asing. Arti dari badan usaha Milik swasta dalam negeri adalah badan usaha yang modalnya dimiliki oleh pihak masyarakat dalam negeri. Sedangkan arti dari badan usaha milik swasta asing adalah badan usaha yang modalnya dimiliki oleh pihak masyarakat asing.

\section{METODE PENELITIAN}

Jenis penelitian ini adalah penelitan literasi. Data diperoleh dari data sekunder atau berbagai informasi kepustakaan (koran, majalah, dan dokumen). Pengumpulan data melalui data pustaka, membaca serta mengolah bahan penelitian terdahulu. Keabsahan data mengggunakan metode trianggulasi. Analisis dengan reduksi, penyajian dan penarikan kesimpulan.

\section{HASIL DAN PEMBAHASAN}

\section{Tata Kelola Badan Usaha Milik Desa}

Badan Usaha Milik Desa (BUMDes) merupakan perwujudan partisipasi Masyarakat Desa secara keseluruhan, sehingga tidak menciptakan model usaha yang di pengaruhi kepimpinan oleh kelompok tertentu ditingkat Desa. Artinya, tata aturan ini terwujud dalam mekanisme kelembagaan yang solid. Penguatan kapasitas kelembagaan akan terarah pada adanya tata aturan yang mengikat seluruh anggota dalam menjalankan tata kelola Badan Usaha Milik Desa.

Dengan adanya modal yang di salurkan oleh Pemerintah Desa untuk dikelola oleh Masyarakat Desa, maka diperlukan partisipasi atau inisiatif Masyarakat Desa dalam menjalankan Badan Usaha Milik Desa untuk mewujudkan Desa yang solid dengan kerjasama Pemintah Desa dan Masyarakatnya.

Dalam mengelola Badan Usaha Milik Desa melalui partisipasi Masyarakat Desa atas dana yang di salurkan oleh Pemerintah Desa, yang kemudian di kelolah oleh Masyakatnya dalam mengelola Sumber Daya Alamnya dengan adanya Sumber Daya Manusia yang mampu mengelolah Badan Usaha Milik Desa. Karena dengan adanya modal yang disalurkan dari Pemerintah Desa dalam bentuk pembiayaan dan kekayaan Desa yang diserahkan untuk di kelolah dari bagian Badan Usaha Milik Desa.

Di dalam Peraturan Menteri Desa No. 4/2015 pasal dua dijelaskan mengenai pendirian BUMDes dimaksudkan sebagai upaya menampung seluruh kegiatan di bidang ekonomi dan pelayanan umum yang 
JISIP: Jurnal Ilmu Sosial dan Ilmu Politik

ISSN. 2442-6962

Vol. 9 No. 2 (2020)

dikelola oleh Desa atau kerja sama antar-Desa.Di pasal-pasal selanjutnya, dirumuskan dengan jelas tujuan mendasar dari terbentuknya BUMDes ini adalah untuk Meningkatkan Perekonomian Desa, Mengoptimalkan Aset Desa agar bermanfaat bagi Masyarakat, Meningkatkan Usaha Masyarakat dalam pengelolaan potensi ekonomi Desa.

Untuk mengelola BUMDes dengan maksimal dan tepat sasaran diperlukan idealisme kuat dari para pengurus BUMDes nantinya bahwa Pengelolaan BUMDes harus diljalankan dengan menggunakan prinsip kooperatif, partisipatif, emansipatif, Transparansi, Akuntable, dan Sustainable, dengan mekanisme keanggotaan dasar dan self help yang dijalankan secara professional dan mandiri. Sejalan dengan hal tersebut, untuk membangun BUMDes diperlukan informasi data yang akurat dan tepat tentang karakteristik lokal Desa, termasuk ciri Sosial Budaya Masyarakatnya dan Peluang Pasar dari Produk Barang dan Jasa yang dihasilkan oleh Masyarakat setempat

\section{Implementasi Kemitraan BUMDes dan Pihak Ketiga}

Implementasi merupakan suatu rangkaian konsep yang menjadi pedoman dalam pelaksanaan suatu pekerjaan, kepemimpinan dan cara bertindak. Salah satubagian dari kebijakan adalah inflementasi kerjasama dilakukan oleh antar pihak ketiga dan BUMDes yaitu menurut AD/ART yang didasarkan pada peraturan desa nomor 4 Tahun 2016. Adapun implementasi kerjasama ini yang dibuat yaitu berupa suatu dokumen perjanjian yang telah disepakati antar beberapa pihak. Pemerintah Desa disini sebagai Komisaris, sedangkan pelaksanaannya di limpahkan ke BUMDes sebagai program Wisata.

Terkait dengan kemitraan antara BUMDes dan Pihak Swasta sesuai dengan Peraturan Desa yang termuat dalam AD/ART, yaitu Pemerintah Desa mengetahui secara tertulis, saling menguntungkan dan dimuat kedalam Peraturan Desa, serta berdampak pada perekonomian Masyarakat dan Sumber Daya Manusia setempat.

Sebagian BUMDes memiliki peluang dalam mengembangkan usaha namun harus berskala besar. Biasanya situasi-situasi seperti ini terletak pada Wilayah Perkotaan dan Pertambangan. Namun, penyertaan modal dari Desa terdapat batas maksimal, sehingga BUMDes sulit untuk berkembang dengan modal yang terbatas. Bekerja sama dengan pihak ketiga adalah salah satu alternatif yang mampu mengatasi masalah modal yang terbatas. Pihak ketiga bisa dijadikan suatu investor untuk pengembangan suatu usaha. Cara ini lebih cepat dan efektif karena mampu mendapatkan modal usaha Desa secara langsung.

Akan Tetapi, proses kerjasama dengan Pihak Ketiga seperti ini haruslah melalui prosedur yang jelas dan legal. Kerja sama harus dikuatkan oleh peraturan khusus yang mengikat dan menjelaskan masing-masing hak dan kewajiban sehingga evaluasi dan kontrol bakal mudah dilakukan. Dengan begitu, kerjasama dengan pihak ketiga benar-benar mampu memberikan manfaat bagi BUMDes.

\section{Collaborative Governance dalam mengelola BUMDes}

Collaborative governance adalah konsep dalam manajemen Pemerintahan sebagai proses fasilitasi oleh berbagai institusi baik Pemerintah, Masyarakat maupun pihak Swasta yang bertujuan untuk menyelesaikan masalah bersama yang tidak bisa di selesaikan oleh satu instansi. Menurut Ansell dan Gash (dalam Aryanti Devi dan Sat Lita 2018:812).

Collaborative Governance mampu mendorong adanya akuntabilitas dan transparansi dalam pengelolaan Badan Usaha Milik Desa yang dikelola oleh Badan Usaha Milik Desa, partisipasi dari Masyarakat dan pihak Swasta hasilnya dapat dirasakan langsung oleh Masyarakat. 
JISIP: Jurnal Ilmu Sosial dan Ilmu Politik

ISSN. 2442-6962

Vol. 9 No. 2 (2020)

Proses kolaborasi antar pemangku kepentingan dalam pengembangan kawasan Minapolitan adalah proses kolaborasi dimulai dari pergerakan prinsip bersama, motivasi bersama, dan pembentukan kapasitas bersama. Setelah tiga hal itu terbentuk dilanjutkan dengan melaksanakan tindakan kolaborasi yang memberikan dampak sementara.

\section{KESIMPULAN}

Dalam pembangunan BUMDes Pemerintah Desa menyalurkan dana Desa untuk dikelola oleh Masyarakat Desa. Pemerintah Desa mengharapakan partisipasi dan inisiatif dari Masyarakat Desa dalam mengelola Badan Usaha Milik Desa supaya terwujudnya Desa yang solid antara Pemerintah Desa dan Masyarakat Desanya.

Selain itu, adanya Collaborative Governance dalam melaksanakan investasi dengan melibatkan Pemerintah, Swasta, Masyarakat, dan Non-Government Organization (NGO) dan masing-masing pihak memiliki peran dan fungsi dalam melaksanakan pembangunan. Peran dan fungsi Pemerintah sebagai instrumen resmi yang dituntut untuk lebih transparan, akuntabel, responsif, efektif dan efesien dalam menciptakan Good Governance. Pembangunan BUMDes juga dapat di lakukan dengan berbagai hal, salah satunya melakukan kerjasama dengan pihak ketiga atau badan usaha lainnya.

Dalam kerjasama Badan Usaha Milik Desa dan Badan Usaha Milik Swasta tidak terlepas dari Pengawasan Pemerintah terhadap sektor Swasta yang terlibat dalam pelaksanaan pembangunan. Juga merupakan perwujudan partisipasi Masyarakat Desa secara keseluruhan sehingga tidak menciptakan model usaha yang di pengaruhi kepimpinan oleh kelompok tertentu ditingkat Desa. Artinya, tata aturan ini terwujud dalam mekanisme kelembagaan yang solid. Penguatan kapasitas kelembagaan akan terarah pada adanya tata aturan yang mengikat seluruh anggota dalam menjalankan atau mengelolah Badan Usaha Milik Desa.

\section{DAFTAR PUSTAKA}

French and Bell. 1978. Organization Development: Behavioral Science Intervention for Organization Improvement. New Jersey: Pretice Hall Inc.

Siagian, Sondang P. 2008. Manajemen Sumber Daya Manusia. Jakarta: Bumi Aksara

Sutoro Eko, dkk. 2015. Policy Paper: Membangun BUMDes yang Mandiri, Kokoh, Dan Berkelanjutan.

Wibowo. 2006. Manajemen Perubahan. Jakarta: Raja Grafindo Persada

Yunanto, dkk. 2014. Strategi Pengembangan Bumdes sebagai Pilar Ekonomi Desa (http://desamembangun.or.id/2014/04/strategi-pengembangan-bumdes-sebagai-pilar-ekonomidesa/police paper forum pengembangan pembaharuan desa (FPPD) 2014). Diakses pada tanggal 12 September 2016. 